\title{
Mayaro virus and dengue virus 1 and 4 natural infection in culicids from Cuiabá, state of Mato Grosso, Brazil
}

\author{
Otacília Pereira Serra1', Belgath Fernandes Cardoso', Ana Lúcia Maria Ribeiro², \\ Fábio Alexandre Leal dos Santos ${ }^{1}$, Renata Dezengrini Slhessarenko ${ }^{3 /+}$
}

\author{
'Universidade Federal de Mato Grosso, Centro de Ciências Básicas da Saúde I, Faculdade de Medicina, \\ Programa de Pós-Graduação em Ciências da Saúde, Cuiabá, MT, Brasil ${ }^{2}$ Universidade Federal de Mato Grosso, \\ Centro de Ciências Básicas da Saúde I, Faculdade de Medicina, Laboratório de Entomologia Médica, Cuiabá, MT, Brasil \\ 3Universidade Federal de Mato Grosso, Centro de Ciências Básicas da Saúde I, Faculdade de Medicina, Laboratório de Virologia, Cuiabá, MT, Brasil
}

This study aimed to verify the diversity of Culicidae species and their frequency of infection with flaviviruses and alphaviruses in Cuiabá, state of Mato Grosso, Brazil. Mosquitoes were captured with Nasci aspirators and hand net in 200 census tracts, identified alive at species level and pooled in one-20 (11,090 mosquitoes, 14 species). Female pools $(n=610)$ were subjected to multiplex seminested-reverse transcription-polymerase chain reaction (RT-PCR) for 11 flavivirus and five alphavirus. Positive pools were tested by single RT-PCR followed by nucleotide sequencing, by RT-PCR for E1 gene [Mayaro virus (MAYV)] and by inoculation in Vero cells (MAYV) or C6/36 cells (flaviviruses). One/171 Aedes aegypti was positive for dengue virus (DENV)-1, 12/403 Culex quinquefasciatus, and four/171 Ae. aegypti for MAYV, which was isolated from two pools containing two nonengorged females of Ae. aegypti and two of Cx. quinquefasciatus. DENV-4 was detected in 58/171 pools of Ae. aegytpi, 105/403 Cx. quinquefasciatus, two/five Psorophora $s p$., two/11 Psorophora varipes/Psorophora albigenu, one/one Sabethes chloropterus, two/five Culex bidens/Culex interfor, and one/one Aedes sp. DENV-4 was isolated from two pools containing three and 16 nonengorged $\mathrm{Cx}$. quinquefasciatus females. Phylogenetic analysis revealed MAYV belongs to genotype L, clustering with human samples of the virus previously identified in the city. Cuiabá has biodiversity and ecosystem favourable for vector proliferation, representing a risk for arbovirus outbreaks.

Key words: dengue virus - Mayaro virus - entomological surveillance

Arboviruses (arthropod-borne viruses) are widely distributed, predominating in tropical areas. These viruses are maintained in nature by epidemiological cycles involving vertebrate hosts and haematophagous arthropod vectors, mainly mosquitoes, ticks, sandflies, and biting midges (Bichaud et al. 2014).

Female mosquitoes are infected by arboviruses during haematophagy in amplification hosts, such as birds, primates, and humans. Vector competence is a component of vector capacity and comprises a variety of biological and genetics factors that combined determine the ability of the invertebrate to transmit infectious agents (Beerntsen et al. 2000). After an extrinsic period of incubation of eight-14 days, a life-long persistent infection is established in the salivary glands of competent vectors (Forrester et al. 2014). Although less frequent, transovarial and venereal transmission also occur in mosquitoes (Coffey et al. 2013).

Flaviviruses transmitted by mosquitoes are divided in those with Culex spp as vectors, usually associated to febrile illness and encephalitis, and those transmitted by Aedes spp, responsible for febrile illness and haem-

doi: 10.1590/0074-02760150270

Financial support: DECIT/SCTIE/MS, CNPq, FAPEMAT/SES-MT, UFMT

OPS and BFC received CAPES master scholarships.

+ Corresponding author: renatadezengrini@yahoo.com.br

Received 17 July 2015

Accepted 19 November 2015 orrhage in their hosts (Figueiredo 2000, Coffey et al. 2013). Medically important flaviviruses already reported in Brazil include yellow fever virus (YFV), dengue virus (DENV) serotypes, Saint Louis encephalitis virus (SLEV), Ilhéus virus (ILHV), Rocio virus (ROCV), Bussuquara virus (BSQV), Cacipacoré virus (CPCV), and recently, West Nile virus (WNV) and Zika virus (ZIKV) (Figueiredo 2000, Batista et al. 2011, WHO 2014). Evidences of flaviviruses circulation in Brazil have also been reported in birds (WNV, SLEV, ROCV, and ILHV), rodents [SLEV and Iguape virus (IGUV)] (Rodrigues et al. 2010, Batista et al. 2011), equines (WNV, SLEV, ROCV, ILHV and CPCV) (PauvolidCorrêa 2008, Pauvolid-Corrêa et al. 2014, Silva et al. 2014), and in vector species (except for WNV) (Cardoso et al. 2010, Figueiredo et al. 2010).

The genus Alphavirus, family Togaviridae, include the eastern (EEEV), western (WEEV), and Venezuelan (VEEV) equine encephalitis viruses (Alice 1951, Iversson et al. 1990), Mayaro virus (MAYV) (Mourão et al. 2012, Zuchi et al. 2014), and Chikungunya virus (CHIKV) (Bronzoni et al. 2005, Formenti 2015). EEEV, VEEV, and WEEV were reported in equines (Aguiar et al. 2008, Pauvolid-Corrêa 2008, Melo et al. 2012) and several alphaviruses (EEEV, VEEV, WEEV, MAYV, Pixuna virus) were described in arthropod vectors (Shope et al. 1964, Estep et al. 2011, Long et al. 2011).

Surveillance studies involving entomology and virology are important tools for monitoring the mosquito fauna and determining intervention strategies to control and pre- 
vent arbovirus epidemics (Regis et al. 2009). Control measures usually target Aedes (Stegomyia) populations in urban areas. Other Culicidae species, also important for arbovirus transmission, are being neglected (Cardoso et al. 2010).

The state of Mato Grosso (MT), located in CentralWest Brazil, presents ecological and climatic conditions favourable to arbovirus circulation. The state is composed of the Amazon, Pantanal, and Cerrado biomes. Cuiabá is the capital of MT and a significant number of confirmed or suspected dengue cases are reported annually in the city (Acendino 2013). Studies involving patients with acute febrile illness during a large dengue outbreak demonstrated the hyperendemicity of DENV and the circulation of SLEV and MAYV in Cuiabá during 2012 (Zuchi et al. 2014, Heinen et al. 2015a, b). However, until the present, studies to evaluate the genetic diversity and frequency of these viruses are lacking. Toward these ends, the present study was aimed at verifying the diversity of Culicidae species and their frequency of infection by flaviviruses and alphaviruses in Cuiabá. Mosquitoes present a life-long persistent infection and are a common host for several arboviruses. Moreover, these invertebrates represent an important tool for determining the epidemiological status of arboviruses in a given area.

\section{MATERIALS AND METHODS}

Study area and Culicidae capture - Cuiabá is located in the south-central region of the state, between the coordinates $15^{\circ} 35^{\prime} 56^{\prime \prime} \mathrm{S} 56^{\circ} 06^{\prime} 01^{\prime \prime} \mathrm{W}$, comprising 3,495,424 $\mathrm{Km}^{2}$ of surface area and 575,480 inhabitants. The climate is semihumid tropical with mean temperature ranging from $21.4-32.8^{\circ} \mathrm{C}$, characterised by a dry season from April-September and a rainy season between October-March (IBGE 2011).

Cuiabá is administratively divided into four regions (north, south, central-east and midwest) and 173 neighbourhoods. The neighbourhoods are further subdivided into 804 census tracts (IBGE 2011), based on demographic density (each census tract represents 250-350 residencies) among which 200 census tracts were randomly selected and located using GPS for adult Culicidae collection between January-April, 2013. Three sites were sampled for at least $30 \mathrm{~min}$ within each selected unit between 01:00 p.m.-05:00 p.m., using Nasci aspirators (Horst Armadilhas, Brazil) and hand net. The adult specimens were transferred immediately to entomological recipients using manual suction tube (Castro catcher) and transported with adequate humidity and temperature conditions provided with access to $20 \%$ glucose solution.

At the laboratory, mosquitoes were identified alive, in a dormant state $\left(4 \mathrm{~min}\right.$ at $\left.4^{\circ} \mathrm{C}\right)$, using a dichotomous key (Forattini 2002) within $12-24 \mathrm{~h}$. Alternatively, a nested polymerase chain reaction (PCR) for Culex quinquefasciatus identification (Smith \& Fonseca 2004) was performed in 193 pools of Culex sp. after DNA extraction, since morphological identification of the species was not possible in these pools. They were grouped according to date, collection site, species, and gender in pools of one20 specimens, and stored at $-80^{\circ} \mathrm{C}$ immediately.
Total RNA and DNA extraction - Specimens were macerated in $800 \mu \mathrm{L}$ of phosphate-buffered saline and centrifuged at $5,500 \mathrm{~g}$ for $4 \mathrm{~min}$ at $4^{\circ} \mathrm{C}$. Total RNA was extracted from $400 \mu \mathrm{L}$ of the supernatant with Trizol reagent (Invitrogen, USA). The pellet obtained during RNA extraction of Culex sp. pools $(n=193)$ was subjected to total DNA extraction. Procedures followed the manufacturer's instructions.

Multiplex seminested-reverse transcription- $P C R$ (RT-PCR) for Flavivirus and Alphavirus genera and nucleotide sequencing - cDNAs were obtained from the samples by RT of the extracted RNA $(9.1 \mu \mathrm{L})$ with genera specific primers [FG2 $(15 \mu \mathrm{M})$ for flaviviruses, cM3W $(100 \mu \mathrm{M})$ for alphaviruses] (Bronzoni et al. 2005), $100 \mathrm{U}$ of reverse transcriptase (Superscript III; Invitrogen), 20 U of RNAse inhibitor (RNAse OUT; Invitrogen), DNTP mix, buffer, dithiothreitol, and temperature conditions following the manufacturer's instructions.

cDNA $(8 \mu \mathrm{L})$ was subjected to duplex-PCR for a NS5 region (958 bp) of Flavivirus and a nsP1 region (434 bp) of Alphavirus genus, followed by three species-specific multiplex-seminested-PCR reactions: flaviviruses 1 (DENV1, 2, 3, YFV, and SLEV), flaviviruses 2 (DENV-4, ILHV, BSQV, IGUV, ROCV, and WNV), and alphaviruses (MAYV, Aura virus, EEEV, WEEV, and VEEV), as previously described (Bronzoni et al. 2005, Cruz et al. 2015).

Positive samples were subjected to single RT-PCR with the same forward and reverse primers for the respective flaviviruses or alphaviruses species identified in the multiplex. The PCR product of these single reactions was purified with polyethylene glycol precipitation protocol, subjected to nucleotide sequencing (3500 genetic analyser; Applied Biossistems, USA), analysed using Geneious R6 v.6.0 and compared through BLASTn with reference sequences available in GenBank [National Center for Biotechnology Information (NCBI)]. Precautions to avoid cross-contamination were carefully undertaken during the entire procedure.

RT-PCR for a region of the envelope gene 1 (E1) of alphaviruses - A region of the E1 of MAYV-positive pools was amplified as described by Powers et al. (2001) with few modifications. Briefly, total RNA was reverse transcribed with the primer $\mathrm{T}_{25} \mathrm{~V}-\mathrm{Mlu}(50 \mu \mathrm{M}), 2.5 \mathrm{mM}$ $\mathrm{MgCL}_{2}, 100 \mathrm{U}$ of reverse transcriptase (GoScript; Promega, USA), 20 U of RNAse inhibitor (RNAse OUT, Invitrogen) and $1 \mathrm{x}$ buffer according to cycling conditions described by the manufacturer. PCR amplification was performed with $6 \mu \mathrm{L}$ of cDNA, $50 \mu \mathrm{M}$ of the primer a10247A, $10 \mathrm{mM}$ of dNTP Mix, $2 \mathrm{mM} \mathrm{MgCL}$, 1x buffer, $1 \mathrm{U}$ of DNA polymerase (GoTaq Hot Start; Promega), and ultrapure water to $50 \mu \mathrm{L}$ reaction volume. Cycling conditions were used as described by the authors, except for the annealing temperature $\left(45^{\circ} \mathrm{C}\right.$ instead of $\left.49^{\circ} \mathrm{C}\right)$. The PCR bands $(1.3 \mathrm{~kb})$ were excised from the agarose gel, purified with nucleospin kit (Macherey-Nagel, Germany), and sequenced as previously described.

Inoculation of positive pools in cell culture - For virus isolation, the supernatants of MAYV-positive pools were inoculated at 1:10 dilution in Vero cells (ATCC CCL-81) 
and the pool positive for DENV-1, 10 for DENV-4, and one for SLEV in C6/36 cells (ATCC CLR-1660) cultivated in 24-well polystyrene plates. After $2 \mathrm{~h}$ of incubation, the inoculum was removed and the monolayers were washed with RPMI-1640 medium (Vero cells) or L-15 medium (C6/36 cells) containing antibiotics. Culture medium (RPMI-1640 or L-15 with 5\% foetal bovine serum) was replaced, the plates maintained at $37^{\circ} \mathrm{C}$ (Vero cells) or $28^{\circ} \mathrm{C}$ (C6/36 cells) in $5 \% \mathrm{CO}_{2}$ incubators, and the monolayers monitored for seven days by examination through inverted microscope. The supernatant was stored at $-80^{\circ} \mathrm{C}$ and the monolayers subjected to total RNA extraction for single-RT-PCR as described above. Three passages in cell culture were performed for each pool.

Data analysis - Data according to census tract, date of capture, species, gender, and number of specimens were compiled using Microsoft Excel 2013. Minimum infection rate (MIR) was calculated using the formula [number of positive pools/total specimens of the species tested) $\mathrm{x}$ 1,000] (Chow et al. 1998) (Table) and presented with confidence interval of 95\% (Epidata Analysis, 2006-2010). Geospatial data were plotted in maps (ArcMap, ESri ArcGIS).

Phylogenetic analysis - A neighbour-joining phylogenetic three was generated with the nucleotide sequences of a region of $\mathrm{NSPl}$ gene amplified from MAYV-positive pools with Tamura-Nei distance model and 1,000 bootstrap (Geneious software 6.0). Reference sequences, previously classified in genotypes $\mathrm{L}$ and $\mathrm{D}$, were retrieved from GenBank (PubMed; NCBI) for comparison. Outgroups included Trocara virus, EEEV, and CHIKV.

Accessions of sequences deposited in GenBank - Nucleotide sequences obtained in this study were deposited at GenBank with the accessions DENV-1 (KP710881), DENV-4 (KP694224, KP694225, KP710879, KP710880, and KP742343), and MAYV (KP710882-KP710893, KP742341, KP742342, and KP954632).

\section{RESULTS}

Mosquitoes collected in Cuiabá - Between JanuaryApril 2013, 11,090 adult Culicidae specimens were collected in Cuiabá, including 6,534 (58.9\%) males and $4,556(41.1 \%)$ females. This resulted in 1,419 pools, of which 610 were comprised of females, 114 collected in the midwest region, 180 in the central-east, 118 from the north, and 198 from the south of the city (Table).

Species belonging to Culex (8,759 specimens; $79 \%$ ) and Aedes (2,294 specimens; $20.7 \%$ ) genera were the most abundant. Eight genera of Culicidae were represented in the collections, comprising 14 species: Ae. aegypti $(\mathrm{n}=$ 2,291), Aedes albopictus $(\mathrm{n}=2)$, Aedes sp. $(\mathrm{n}=1)$, Culex bidens or Culex interfor $(\mathrm{n}=7), C x$. quinquefasciatus $(\mathrm{n}$ $=8,751)$, Culex spinosus $(\mathrm{n}=1)$, Galindomyia $\mathrm{sp} .(\mathrm{n}=1)$, Limatus sp. $(\mathrm{n}=8)$, Mansonia wilsoni $(\mathrm{n}=4)$, Psorophora (Psorophora) $\mathrm{sp} .(\mathrm{n}=7)$, Psorophora ciliata $(\mathrm{n}=1)$, Psorophora varipes or Psorophora albigenu $(\mathrm{n}=14), S a$ bethes chloropterus $(\mathrm{n}=1)$, and Uranotaenia $\mathrm{sp} .(\mathrm{n}=1)$.

Frequency of infection by arboviruses in adult female mosquitoes - Since only females are haematophagous and due to the large number of specimens collected in the experiment, only the 610 female pools were tested for arboviruses. Of these, $28 \%(n=171)$ were positive for flaviviruses and $2.6 \%(\mathrm{n}=16)$ for alphaviruses (Table). Pools of adult females positive for more than one arbovirus represented $0.1 \%$, with three of these five pools with dual infection by DENV and MAYV being composed of only one female without signs of engorgement.

One pool obtained at Bela Vista neighbourhood, captured in February 2013 in the central-east region of Cuiabá containing 18 nonengorged specimens of $A e$. aegypti, was positive for DENV-1 (MIR $=0.92 \pm 1.7)$ (KP710881), DENV-4, and MAYV (KP710882) (Fig. 1). Its nucleotide sequence presented, respectively, $99 \%$ identity with the DENV-1 HNRG27213 (KC692513.1), genotype V, American/African lineage strain, obtained from humans in 2010 in Argentina, and 99\% with the MAYV sequence MAY_BR/MT_CBA_230/2012 obtained from humans in 2012, in Cuiāá (KJ̈879253.1). One pool obtained in other collection site in the same neighbourhood, containing one female of $C x$. quinquefasciatus captured on the same day, was positive for SLEV. The nucleotide sequence (KJ801827) presented $99 \%$ of identity with the SLEV previously identified in humans with acute febrile illness in MT during a severe dengue outbreak, belonging to genotype VA (Heinen et al. 2015b) (Fig. 1A).

DENV-4 was detected in $171(28 \%)$ pools: $58 / 171$ (33.9\%) of Ae aegypti, one/one (100\%) of Aedes spp, $105 / 403$ (26\%) of Cx. quinquefasciatus, two/five (40\%) of Cx. bidens/interfor, two/five (40\%) of Psorophora sp., two/11 (18.2\%) of Ps. varipes/albigenu, and one/ one (100\%) of Sa. chloropterus (Fig. 1A, Table). Among these pools, 44 Culex spp, two Psorophora spp, and the $\mathrm{Sa}$. chloropterus pool contained engorged females. Nucleotide sequencing demonstrated the identity to be 99\% to DENV-4 isolates of genotype II from Manaus, state of Amazonas (H780563, JQ513343.1, and H780556, JQ513342.1). DENV-4 was isolated from two pools of Cx. quinquefasciatus containing 16 (\#806, 1st passage) and three (\#329, 1st passage) nonengorged females.

Pools of Cx. quinquefasciatus $(12 / 403 ; 3 \%)$ and $A e$. aegypti $(4 / 171 ; 2.3 \%)$ obtained in 12 census tracts were positive for MAYV (Fig. 1B, Table), among which five were also positive to DENV-4. Two pools positive only to MAYV containing two nonengorged females, one of Cx. quinquefasciatus (\#489, 3rd passage; KP742341) and one of Ae. aegypti (\#958, 1st passage; KP742342), presented cytopathic effect after inoculation in Vero cells. Virus isolation was confirmed through single-RT-PCR and nucleotide sequencing.

Unspecific amplification of mosquito sequences was identified within the $1.3 \mathrm{~kb}$ amplicon obtained through the E1 gene RT-PCR in MAYV positive pools. Phylogenetic analysis of the nsP1 partial sequences obtained from these pools revealed a similarity with sequences of the virus obtained from human samples in MT. These sequences presented a high similarity with other sequences of MAYV belonging to genotype L from Ixodes spp, Haemagogus janthinomys and humans in the state of Pará (PA) (Fig. 2).

Among the four administrative regions of Cuiabá, the south presented $44.4 \%$ (88/198) pools positive for arboviruses, followed by central-east with $33.8 \%$ (61/180), 


\section{TABLE}

Natural infection frequency and minimum infection rate (MIR) of adult Culicidae female pools positive for dengue virus 4 (DENV-4) and Mayaro virus (MAYV) by administrative region of Cuiabá, state of Mato Grosso, Brazil, 2013

\begin{tabular}{|c|c|c|c|c|c|c|}
\hline \multirow[b]{2}{*}{ Species } & \multirow[b]{2}{*}{ Neighbourhood } & \multirow{2}{*}{$\begin{array}{c}\text { Collected } \\
\text { pools } \\
\text { (n) }\end{array}$} & \multirow{2}{*}{$\begin{array}{l}\text { Females } \\
\text { (n) }\end{array}$} & \multirow{2}{*}{$\begin{array}{c}\text { Positive } \\
\text { pools } \\
\text { (n) }\end{array}$} & \multicolumn{2}{|c|}{$\begin{array}{l}\text { MIR } \\
( \pm \mathrm{CI})\end{array}$} \\
\hline & & & & & DENV-4 & MAYV \\
\hline \multicolumn{7}{|l|}{ North } \\
\hline Aedes aegypti & $\begin{array}{l}\text { Paiaguás, Centro Político Administrativo, } \\
\text { Morada da Serra, Primeiro de Março, Três Barras }\end{array}$ & 29 & 129 & 4 & $\begin{array}{l}31.01 \\
( \pm 1.7)\end{array}$ & - \\
\hline Aedes sp. & Jardim Vitória & 1 & 1 & 1 & 1,000 & - \\
\hline $\begin{array}{l}\text { Culex bidens/ } \\
\text { Culex interfor }\end{array}$ & Três Barras & 1 & 1 & 0 & - & - \\
\hline Culex quinquefasciatus & $\begin{array}{l}\text { Paiaguás, Centro Político Administrativo, } \\
\text { Morada da Serra, Três Barras, Primeiro de Março }\end{array}$ & 83 & 768 & 12 & $\begin{array}{c}15.42 \\
( \pm 3.92)\end{array}$ & - \\
\hline Culex spinosus & Morada da Serra & 1 & 1 & 0 & - & - \\
\hline Psorophora sp. & Jardim Vitória & 1 & 1 & 0 & - & - \\
\hline $\begin{array}{l}\text { Psorophora varipes/ } \\
\text { Psorophora albigenu }\end{array}$ & Centro Político Administrativo & 2 & 4 & 0 & - & - \\
\hline \multicolumn{7}{|l|}{ South } \\
\hline Ae. aegypti & $\begin{array}{l}\text { Jardim Petrópolis, Jardim Paulista, Campo Velho, } \\
\text { Pedra 90, Tijucal, São João Del Rei, Altos do Coxipó, } \\
\text { Coxipó, Jardim das Palmeiras, Santa Laura, } \\
\text { São Sebastião, Osmar Cabral, Parque Geórgia, } \\
\text { Residencial Coxipó,São Francisco, Nova Esperança, } \\
\text { Jardim Industriário, Jardim Comodoro, } \\
\text { Parque Cuiabá, Parque Atalaia, Jardim Florianópolis }\end{array}$ & 45 & 220 & $27^{a}$ & $\begin{array}{l}113.64 \\
( \pm 1.13)\end{array}$ & $\begin{array}{c}9.09 \\
( \pm 3.97)\end{array}$ \\
\hline $\begin{array}{l}\text { Cx. bidens/ } \\
\text { Cx. interfor }\end{array}$ & Pedra 90 & 1 & 1 & 0 & - & - \\
\hline Cx. quinquefasciatus & $\begin{array}{l}\text { Campo Velho, Pedra 90, Tijucal, São João Del Rei, } \\
\text { Altos do Coxipó, Coxipó, Jardim Fortaleza, } \\
\text { Santa Laura, Osmar Cabral, Bela Marina, } \\
\text { Jardim Gramado, Residencial Coxipó, } \\
\text { São Francisco, Jardim Industriário, Parque Atalaia, } \\
\text { Parque Cuiabá, Jardim Comodoro, } \\
\text { Nossa Senhora Aparecida, Jardim Petrópolis, } \\
\text { Jardim Paulista, São Sebastião, Parque Geórgia, } \\
\text { Nova Esperança, Jardim Passaredo, Jardim Presidente }\end{array}$ & 149 & 1,409 & 58 & $\begin{array}{c}39.61 \\
( \pm 2.9)\end{array}$ & $\begin{array}{c}1.39 \\
( \pm 17.6)\end{array}$ \\
\hline Psorophora sp. & Osmar Cabral & 1 & 1 & 1 & 1,000 & - \\
\hline $\begin{array}{l}\text { Ps. varipes/ } \\
\text { Ps. albigenu }\end{array}$ & Jardim Presidente & 1 & 1 & 1 & 1,000 & - \\
\hline Sabethes chloropterus & Parque Cuiabá & 1 & 1 & 1 & 1,000 & - \\
\hline \multicolumn{7}{|l|}{ Central-east } \\
\hline Ae. aegypti & $\begin{array}{l}\text { Araés, Lixeira, Bosque da Saúde, Poção, } \\
\text { Dom Aquino, Areão, Jardim das Américas, Pedregal, } \\
\text { Terra Nova, Carumbé, Bela Vista, Jardim Itália, } \\
\text { Santa Cruz, UFMT, Boa Esperança, Jardim Leblon, } \\
\text { Praeirinho, Terceiro, Grande Terceiro, } \\
\text { Recanto dos Pássaros, Jardim Imperial, } \\
\text { Jardim Petrópolis, Jardim Califórnia, Campo Velho, } \\
\text { Campo Verde, Jardim Universitário, Altos do Coxipó, } \\
\text { Residencial Itamaraty, Planalto, Novo Horizonte }\end{array}$ & 54 & 457 & $25^{b}$ & $\begin{array}{c}46.12 \\
( \pm 2.48)\end{array}$ & $\begin{array}{c}4.23 \\
( \pm 9.2)\end{array}$ \\
\hline Ae. albopictus & Novo Mato Grosso & 1 & 1 & 0 & - & - \\
\hline $\begin{array}{l}\text { Cx. bidens/ } \\
\text { Cx. interfor }\end{array}$ & Bosque da Saúde, Bela Vista & 2 & 2 & 2 & 1,000 & - \\
\hline
\end{tabular}




\begin{tabular}{|c|c|c|c|c|c|c|}
\hline \multirow[b]{2}{*}{ Species } & \multirow[b]{2}{*}{ Neighbourhood } & \multirow{2}{*}{$\begin{array}{c}\text { Collected } \\
\text { pools } \\
\text { (n) }\end{array}$} & \multirow{2}{*}{$\begin{array}{l}\text { Females } \\
\text { (n) }\end{array}$} & \multirow{2}{*}{$\begin{array}{c}\text { Positive } \\
\text { pools } \\
\text { (n) }\end{array}$} & \multicolumn{2}{|c|}{$\begin{array}{c}\text { MIR } \\
( \pm \mathrm{CI})\end{array}$} \\
\hline & & & & & DENV-4 & MAYV \\
\hline \multicolumn{7}{|l|}{ Central-east } \\
\hline Cx. quinquefasciatus & $\begin{array}{c}\text { Araés, Lixeira, Bosque da Saúde, Poção, } \\
\text { Terceiro, Dom Aquino, Areão, } \\
\text { Jardim das Américas, Pedregal, Terra Nova, Car- } \\
\text { umbé, Bela Vista, Jardim Itália, } \\
\text { Santa Cruz, UFMT, Boa Esperança, } \\
\text { Jardim Leblon, Grande Terceiro, Terceiro, } \\
\text { Praeirinho, Recanto dos Pássaros, } \\
\text { Jardim Imperial, Campo Velho, Campo Verde, } \\
\text { Jardim Universitário, Jardim dos Ipês, } \\
\text { Altos do Coxipó, Planalto, Jardim Eldorado, } \\
\text { Novo Horizonte, Jardim Petrópolis, } \\
\text { Residencial Itamaraty, Novo Mato Grosso }\end{array}$ & 114 & 628 & $31^{a}$ & $\begin{array}{c}38.21 \\
( \pm 1.74)\end{array}$ & $\begin{array}{c}16 \\
( \pm 2.7)\end{array}$ \\
\hline Limatus sp. & UFMT, Recanto dos Pássaros & 2 & 3 & 0 & - & - \\
\hline Psorophora sp. & Araés, UFMT & 2 & 2 & 1 & 500 & - \\
\hline $\begin{array}{l}\text { Ps. varipes/ } \\
\text { Ps. albigenu }\end{array}$ & $\begin{array}{l}\text { Araés, Bosque da Saúde, UFMT, } \\
\text { Novo Horizonte, Dom Aquino }\end{array}$ & 5 & 5 & 1 & 200 & - \\
\hline \multicolumn{7}{|l|}{ Midwest } \\
\hline Ae. aegypti & $\begin{array}{l}\text { Barra do Pari, Santa Isabel, Coophamil, } \\
\text { Novo Terceiro, Porto, Cidade Alta, Goiabeiras, } \\
\text { Jardim Cuiabá, Duque de Caxias, Novo Colorado, } \\
\text { Jardim Mariana, Quilombo, Despraiado, } \\
\text { Santa Marta, Araés, Lixeira, Bosque da Saúde, } \\
\text { Alvorada, Paiaguás, Centro Sul, Centro Norte }\end{array}$ & 43 & 281 & 6 & $\begin{array}{c}21.35 \\
( \pm 1.73)\end{array}$ & - \\
\hline $\begin{array}{l}\text { Cx. bidens/ } \\
\text { Cx. interfor }\end{array}$ & Jardim Mariana & 1 & 3 & 0 & - & - \\
\hline Cx. quinquefasciatus & $\begin{array}{c}\text { Barra do Pari, Santa Isabel, Coophamil, } \\
\text { Cidade Alta, Porto, Goiabeiras, } \\
\text { Duque de Caxias, Jardim Cuiabá, Novo Colorado, } \\
\text { Jardim Mariana, Quilombo, Despraiado, } \\
\text { Santa Marta, Araés, Lixeira, Alvorada, } \\
\text { Bosque da Saúde, Paiaguás, Santa Isabel, } \\
\text { Centro Sul, Centro Norte }\end{array}$ & 57 & 620 & $12^{c}$ & $\begin{array}{c}19.35 \\
( \pm 5.45)\end{array}$ & - \\
\hline Galindomyia sp. & Barra do Pari & 1 & 1 & 0 & - & - \\
\hline Limatus sp. & Barra do Pari, Quilombo, Centro Norte & 4 & 4 & 0 & - & - \\
\hline Mansonia wilsoni & Coophamil, Despraiado & 2 & 4 & 0 & - & - \\
\hline Psorophora ciliata & Santa Marta & 1 & 1 & 0 & - & - \\
\hline Psorophora sp. & Araés, Alvorada & 1 & 1 & 0 & - & - \\
\hline $\begin{array}{l}\text { Ps. varipes/ } \\
\text { Ps. albigenu }\end{array}$ & $\begin{array}{c}\text { Quilombo, Santa Marta, Araés, } \\
\text { Bosque da Saúde, Alvorada }\end{array}$ & 3 & 4 & 0 & - & - \\
\hline Uranotaenia sp. & Despraiado & 1 & 1 & 0 & - & - \\
\hline
\end{tabular}

a: MAYV was isolated from one pool containing two females of Ae. aegypti captured in São Sebastião and from another with two females of Cx. quinquefasciatus collected at Bela Vista neighbourhood, both positive only for MAYV by reverse transcription-polymerase chain reaction; $b$ : one of these pools containing 18 females of Ae. aegypti captured at Bela Vista neighbourhood was positive for DENV-1; $c$ : DENV-4 was isolated from one pool containing three females of $C x$. quinquefasciatus captured at Porto neighbourhood and from another with 16 females of the same species captured in Pedra 90 neighbourhood; CI: confidence interval; UFMT: Universidade Federal de Mato Grosso.

north with $14.4 \%(17 / 118)$, and midwest with $15.8 \%$ (18/114). No statistical difference was observed for sylvatic species (Psorophora, Sabethes, Limatus, Mansonia, and Uranotaenia) distribution between the four administrative regions (Table).

\section{DISCUSSION}

This is the first study to investigate the diversity of $\mathrm{Cu}$ licidae species and their frequency of infection by medically important flaviviruses and alphaviruses in Cuiabá. $C x$. quinquefasciatus and Ae. aegypti occurrence has been 

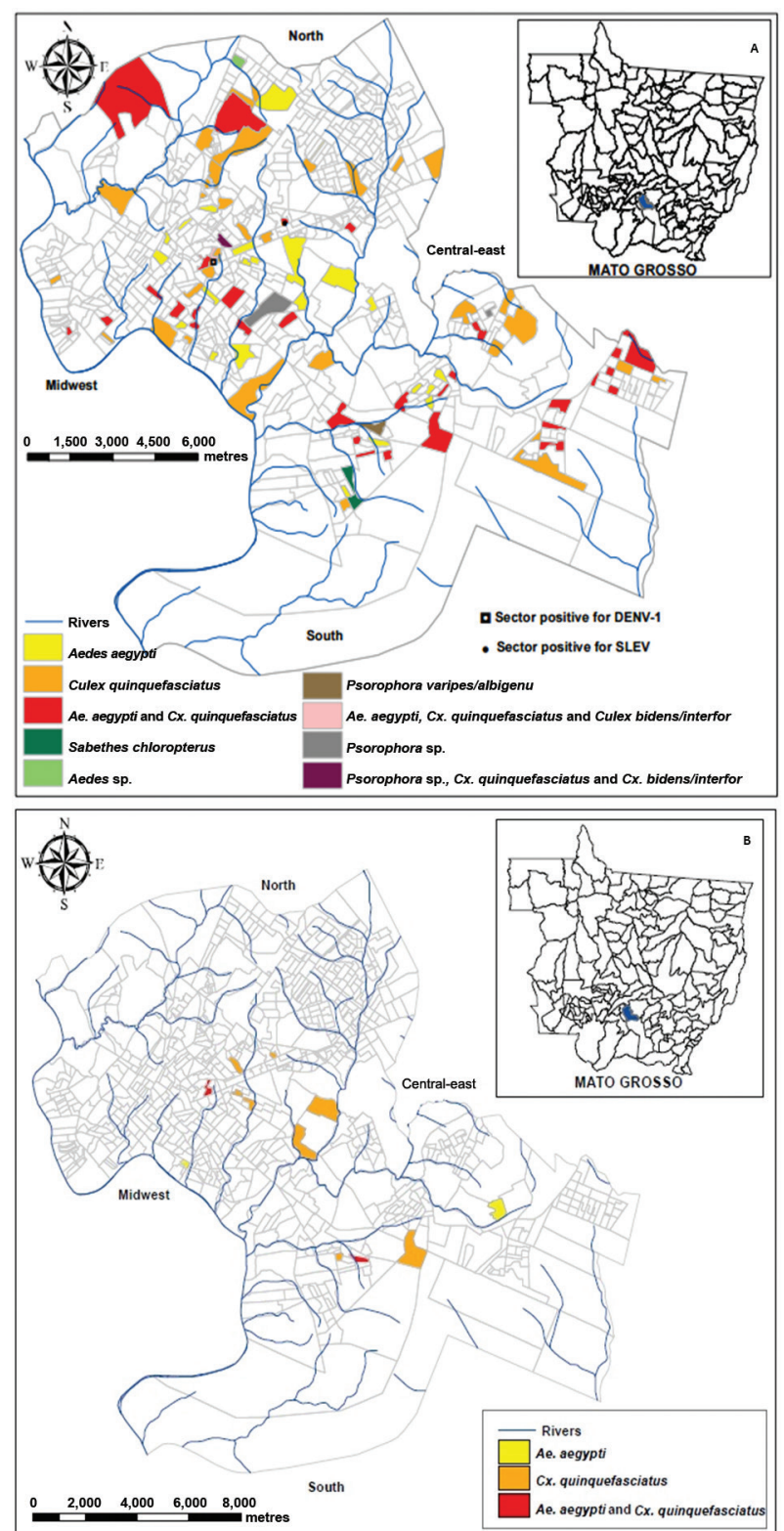

Fig. 1: distribution of adult culicid female pools positive for dengue virus serotype 1 (DENV-1), DENV-4, and for Saint Louis encephalitis virus (SLEV) (1A) and Mayaro virus (1B) in urban sectors of the city of Cuiabá, state of Mato Grosso, Brazil.

previously documented in Cuiabá (Campos \& Andrade 2003, Carvalho-Leandro et al. 2010). In 2012, DENV hyperendemicity and SLEV and MAYV circulation were also reported in the city (Zuchi et al. 2014, Heinen et al. $2015 \mathrm{a}, \mathrm{b}$ ). In the same year, the frequency of transovarial infection of Ae. aegypti by DENV-4 was $10.5 \%$ in a region of Cuiabá with a high incidence of dengue (Cruz et al. 2015). However, studies involving adult Culicidae and other arboviruses were lacking in this area. Generally, mosquitoes infected by arboviruses are detected for up to six weeks prior to the beginning of an outbreak (Chow et al. 1998). Moreover, infected mosquitoes carry the virus for their entire life, presenting as an epidemiological indicator of arboviruses circulation in a given area.
Cx. quinquefasciatus, the most abundant species, was present in $92 \%$ of the census tracts and was positive for DENV-4, SLEV, and MAYV (Fig. 1, Table). The prevalence of this species might have resulted from the competitive success for breeding sites and blood meal sources in comparison to other culicids. This species is a competent vector for WNV, SLEV, Oropouche virus, and MAYV (Hoch et al. 1987, Segura \& Castro 2007, Abad-Franch et al. 2012).

Data concerning SLEV circulation in Brazil are probably underestimated. Human cases were reported in the Amazon Region, in the city of São Paulo (Rocco et al. 2005, Mondini et al. 2007), and in Cuiabá (Heinen et al. 2015b). One pool containing a nonengorged female of $C x$. quinquefasciatus from midwest Cuiabá was positive for SLEV subgenotype V-A during this study; the nucleotide sequence of which presented a high similarity to the SLEV detected in humans in this same area in 2012 (Heinen et al. 2015b).

MAYV is endemic in the Amazon Region, where is maintained in sylvatic cycles involving Ha. janthinomys as the main vector and birds and primates as amplifying hosts. Human infections are generally incidental, due to occupational exposure (Pinheiro \& Leduc 1998). An urban cycle of transmission has been proposed for MAYV in Manaus (Mourão et al. 2012) and Cuiabá (Zuchi et al. 2014). In this study, viral isolation was achieved from two pools of Cx. quinquefasciatus and Ae. aegypti, which were only positive to MAYV, with no signs of engorgement. Isolation of MAYV from other Culicidae species such as Aedes, Culex, Psorophora, Sabethes, and Haemagogus spp has been reported (Pinheiro \& Leduc 1998, Long et al. 2011). Vector competence of $C x$. quinquefasciatus and Ae. aegypti for MAYV transmission has been demonstrated experimentally (Long et al. 2011, Abad-Franch et al. 2012). The importance of these species as MAYV vectors is based on their urban and anthropophilic habits and their wide geographic distribution, favouring the contact with humans and, therefore, viral transmission and urbanisation of MAYV. The positivity of these species to MAYV in the present study might have resulted from natural infection in the mosquito, since most of the positive pools were not engorged and therefore the virus detected was not acquired from the blood. Additional studies are necessary to elucidate the involvement of these mosquito species in the epidemiological cycle of MAYV.

Nucleotide sequences of MAYV obtained from $C x$. quinquefasciatus showed $98-100 \%$ identity with sequences of the virus obtained from humans in Cuiabá (KJ879256.1; KJ879257.1) and in the city of Várzea Grande, MT (KJ879258.1). In a similar vein, sequences obtained from Ae. aegypti showed $99-100 \%$ of identity with virus sequences obtained from humans in Cuiabá (KJ879253.1; KJ869256.1) during 2012, indicating the same virus was identified in humans and in mosquitoes in MT (Zuchi et al. 2014). The patients positive for MAYV in Cuiabá in 2012 were urban residents and denied recent travel to rural or sylvatic areas. Associations to sex and occupation were not identified (Forattini 2002). Taken together, these findings corroborate the occurrence of urban transmission in Cuiabá. 


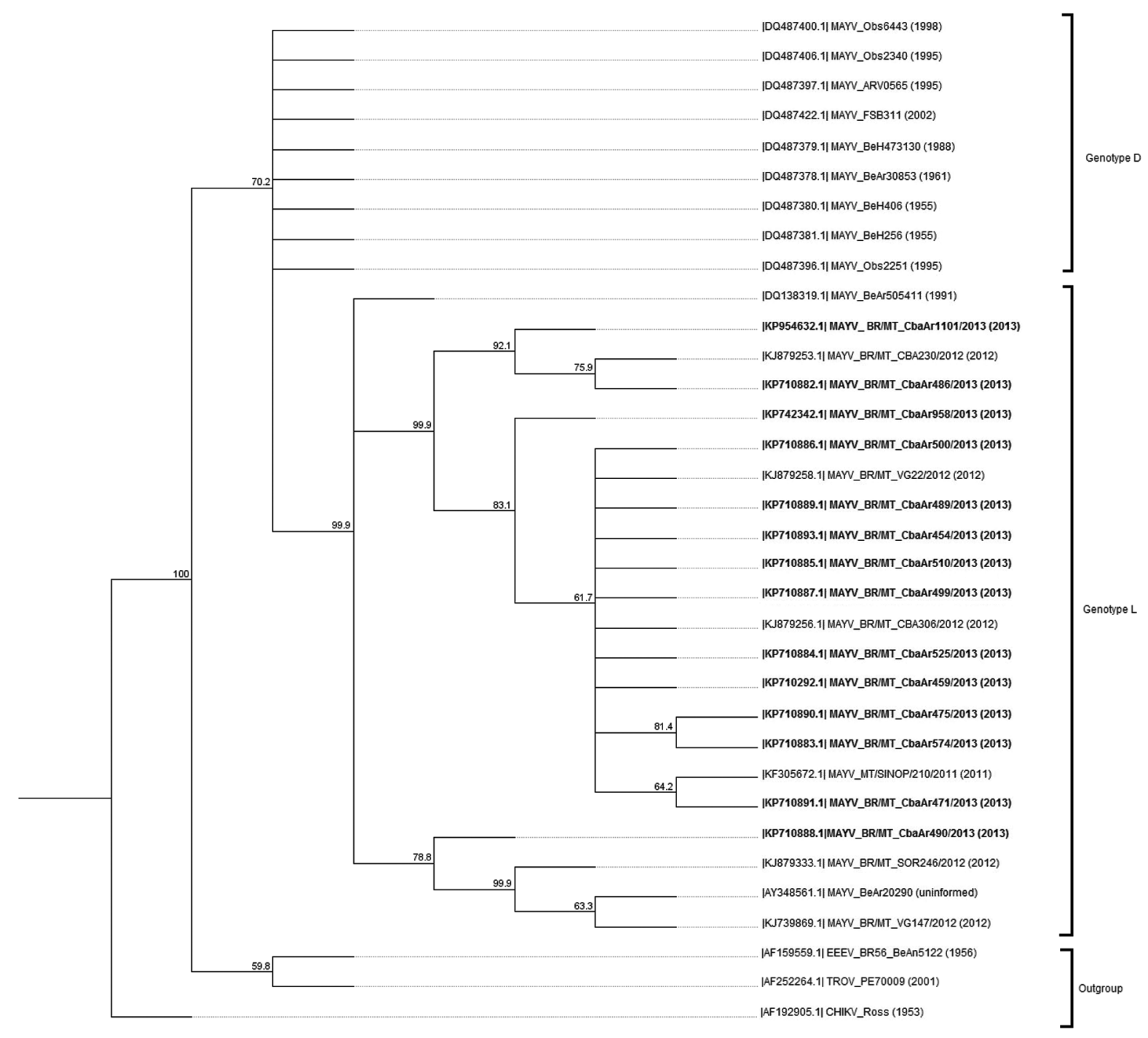

Fig. 2: phylogenetic analysis of Mayaro virus (MAYV) nsP1 gene partial sequences identified in culicids captured in the urban area of Cuiabá, state of Mato Grosso, Brazil, in comparison with reference sequences obtained through GenBank (National Center for Biotechnology Information). Tree was generated by neighbour-joining method and Tamura-Nei distance method, 1,000 bootstrap replicates. Outgroup consisted of Trocara virus (TROV), eastern equine encephalitis virus (EEEV), and Chikungunya virus (CHIKV). Sequences identified in this study are in bold.

Although $E 2 / E 1$ structural sequences of alphaviruses are more appropriate for phylogenetic analysis, a similarity in the clustering among $E 2 / E 1$ and nsP1 sequences has been described (Vieira et al. 2015). This finding was also observed in this study. MAYV nucleotide sequences formed a monophyletic group separated in clusters comprising genotypes $\mathrm{L}$ and $\mathrm{D}$. The genotype $\mathrm{D}$ is composed of several isolates from South America and genotype L of strains from northern and central regions of Brazil (Powers et al. 2006, Vieira et al. 2015).

All mosquitoes and human sequences of nsP1 from MT grouped within the genotype L of MAYV in the same cluster and are in close proximity to sequences obtained from Ixodes spp and humans in PA. These results indicate that the same virus might be circulating in mosquitoes and humans in this region. Vieira et al. (2015) suggested that MAYV isolates consist of a sympatric group in MT.

Ae. aegypti females were the second most frequent specimens, captured in 165/200 census tracts of Cuiabá. This species is highly anthropophilic, extremely adaptable to diverse urban environmental conditions, and it is widely distributed in Brazil. Monitoring the distribution and frequency of infection of this species is important in identifying the hot spots for arbovirus transmission in the city (Regis et al. 2009). Ae. aegypti has also been implicated in the transmission cycle of other arboviruses already described in Brazil, such as YFV, ROCV, ILHV, BSQV, ZIKV, and CHIKV (Schatzmayr 2001, Vega-Rúa et al. 2014). 
DENV-1, 4 were identified among culicids in Cuiabá. The increased incidence of DENV-4 in humans in the metropolitan area of Cuiabá during 2011-2012 (Heinen et al. 2015a) was accompanied by a significant frequency of this serotype in mosquitoes during 2013. Among 171 pools positive for DENV-4, 58/171 (9\%) were of Ae. aegypti. Culex, Psorophora, and Sabethes spp positivity to DENV-4 may have resulted from the presence of viraemic blood in the abdomen of engorged females, due to haematophagy in humans or from natural infection of these specimens. $\mathrm{Ng}$ et al. (2011) also reported the detection of viruses in mosquitoes arising from the alimentary source. Natural infection of different mosquito species with arboviruses is commonly described; although there is no confirmed association with vector competence for DENV serotypes for these species, i.e., participation in the transmission cycle. Moreover, Cx. quinquefasciatus naturally infected by DENV-2 after a blood meal on viraemic host was already described (Luo 1993) and Haemagogus leucocelenus positivity for DENV-1 in Bahia, where a sylvatic cycle of transmission was suggested, represents a possible adaptation of urban viruses in sylvatic mosquitoes and their maintenance in enzootic cycles (Figueiredo et al. 2010). In Brazil, natural infection of Psorophora spp by Maguari virus, ILHV, MAYV, YFV, and ROCV (de Souza-Lopes et al. 1981), and of Sa. chloropterus by SLEV, an important YFV vector, were reported previously (Svoboda et al. 2014).

Most of the collected mosquitoes and positive pools are from the south, followed by central-east, north and midwest regions of the city. These regions also present socioeconomic conditions favouring the proliferation of mosquito populations. The south and central-east regions presented elevated MIR relative to other regions. In 2013 alone, 3,750 dengue cases were reported in Cuiabá (SES-MT 2014). The neighbourhoods with higher dengue incidence are part of the administrative regions with a high number of positive pools. Higher rates of Ae. aegypti infection correlate with increased possibility of DENV transmission and are directly linked to human infections, since most adult females become infected after biting an infected host (Chow et al. 1998, Urdaneta et al. 2005, Zeidler et al. 2008).

Dengue hyperendemicity was previously described in Manaus, in the city of Rio de Janeiro, and Cuiabá (Nogueira \& Eppinghaus 2011, Bastos et al. 2012, Heinen et al. 2015a). The co-circulation of more than one DENV serotype associated to susceptibility of human populations to the serotypes and density of Ae. aegypti populations are factors contributing to the occurrence of epidemics (Guedes 2012). For these reasons, understanding vector population characteristics is essential to establish appropriate vector control measures and, consequently, checking arboviruses dissemination.

The high mosquito population density identified in the study may explain dual positivity for MAYV and DENV-4 detected in five pools. Since most of the pools are composed of more than one specimen, probably different females were infected by different arboviruses, although co-infection could also occur and one or both viruses could also originate from haematophagy of a viraemic hosts in the pools with engorged females. Co-infections by
DENV and CHIKV in Ae. albopictus pools have been described from Africa, raising the possibility of human dual infection through one single mosquito bite. Experimentally, co-infection and super-infection of this species by both viruses have been demonstrated (Vazeille et al. 2010).

Cuiabá represents a heterogeneous environmental setting. The uncontrolled demographic growth, precarious sanitary conditions, and of infrastructure observed in several neighbourhoods, associated to the presence of growing areas, parks, streams, and rivers inside the urban perimeter, may explain the presence of sylvatic culicid species in the study. Permanent preservation areas (extensive areas with native sylvatic woods in the urban perimeter protected by law) and parks also allow the existence of birds and primates that are important amplifying hosts for several arboviruses (Navarro-Silva et al. 2004).

The knowledge of culicid species diversity and their frequency of infection by arboviruses in regions where epidemics are frequent are important in predicting which arboviruses may circulate in humans or disseminate after their introduction. These observations highlight the necessity to deepen our understanding about the epidemiological cycle and molecular evolution of these viruses in MT, as well as to improve entomological surveillance measures.

\section{ACKNOWLEDGEMENTS}

To the UFMT Veterinary Virology Lab Team, for making available facilities for virus isolation, to Fiocruz-AM, for nucleotide sequencing, to Dr Laura HV Gil (Fiocruz-Recife), for providing the C6/36 cells, to Dr Juliana Chavez, for providing the nucleospin kit, to Ricardo Heinen, for assistance with ArcMap software, and to Fernanda C Pereira, Breno H Gondim, Nayara Zuchi and Letícia B Heinen, for assistance during the experimental sampling.

\section{REFERENCES}

Abad-Franch F, Grimmer GH, Paula VS, Figueiredo LTM, Braga WSM, Luz SLB 2012. Mayaro virus infection in Amazonia: a multimodel inference approach to risk factor assessment. PLoS Negl Trop Dis 6: e1846.

Acendino A 2013. Estado divulga dados de dengue de 1 de janeiro a 28 de novembro de 2013. Available from: saude.mt.gov.br/noticia/3521.

Aguiar DM, Cavalcante GT, Lara MCCSH, Villalobos EMC, Cunha EMS, Okuda LH, Stéfano E, Nassar AFC, Souza GO, Vasconcellos SA, Labruna MB, Camargo LMA, Gennari SM 2008. Prevalência de anticorpos contra agentes virais e bacterianos em equideos do município de Monte Negro, Rondônia, Amazônia ocidental brasileira. Braz J Vet Res Anim Sci 45: 269-276.

Alice FJ 1951. Encefalomielite equina na Bahia - estudo de três amostras isoladas. Rev Bras Biol 11: 125-144.

Bastos MS, Figueiredo RMP, Ramasawmy R, Itapirema E, Gimaque JBL, Santos LO, Figueiredo LTM, Mourão MPG 2012. Simultaneous circulation of all four dengue serotypes in Manaus, state of Amazonas, Brazil in 2011. Rev Soc Bras Med Trop 45: 393-394.

Batista WC, Tavares GSB, Vieira DS, Honda ER, Pereira SS, Tada MS 2011. Notification of the first isolation of Cacipacore virus in a human in the state of Rondônia, Brazil. Rev Soc Bras Med Trop 44: 528-530.

Beerntsen BT, James AA, Christensen BM 2000. Genetics of mosquito vector competence. Microbiol Mol Biol Rev 64: 115-137. 
Bichaud L, Lamballerie X, Alkan C, Izri A, Gould EA, Charrel RN 2014. Arthropods as a source of new RNA viruses. Microb Pathog 77: 136-141.

Bronzoni RVM, Baleotti FG, Nogueira RMR, Nunes M, Figueiredo LTM 2005. Duplex reverse transcription-PCR followed by nested PCR assays for detection and identification of Brazilian alphaviruses and flaviviruses. J Clin Microbiol 43: 696-702.

Campos J, Andrade CFS 2003. Larval susceptibility of Aedes aegypti and Culex quinquefasciatus populations to chemical insecticides. Rev Saude Publica 37: 523-527.

Cardoso JC, Paula MB, Fernandes A, Santos E, Almeida MAB, Fonseca DF, Sallum MAM 2010. Novos registros e potencial epidemiológico de algumas espécies de mosquitos (Diptera, Culicidae) no estado do Rio Grande do Sul. Rev Soc Bras Med Trop 43: 552-556.

Carvalho-Leandro D, Ribeiro ALM, Rodrigues JSV, Albuquerque CMR, Acel AM, Santos FAL, Leite Jr DP, Myiazaki RD 2010. Temporal distribution of Aedes aegypti Linnaeus (Diptera, Culicidae) in a Hospital in Cuiabá, state of Mato Grosso, Brazil. Rev Bras Entomol 54: 701-706.

Chow VTK, Chan YC, Yong R, Lee KM, Lim LK, Chung YK, LamPhua SG, Tam BT 1998. Monitoring of dengue viruses in fieldcaught Aedes aegypti and Aedes albopictus mosquitoes by a type-specific polymerase chain reaction and cycle sequencing. Am J Trop Med Hyg 58: 578-586.

Coffey LL, Forrester N, Tsetsarkin K, Vasilakis N, Weaver SC 2013. Factors shaping the adaptive landscape for arboviruses: implications for the emergence of disease. Future Microbiol 8: 155-176.

Cruz LCTA, Serra OP, Santos FAL, Ribeiro ALM, Dezengrini-Slhessarenko R, Santos MA 2015. Natural transovarial transmission of dengue virus 4 in Aedes aegypti from Cuiabá, Mato Grosso, Brazil. Rev Soc Bras Med Trop 48: 18-25.

de Souza-Lopes O, Sacchetta LA, Francy DB, Jakob WL, Calisher $\mathrm{CH}$ 1981. Emergence of a new arbovirus disease in Brazil. III. Isolation of Rocio virus from Psorophora ferox (Humboldt, 1819). Am J Epidemiol 113: 122-125.

Estep LK, McClure CJW, Burkett-Cadena ND, Hassan HK, Hicks TL, Unnasch TR, Hill GE 2011. A multi-year study of mosquito feeding patterns on avian hosts in a southeastern focus of eastern equine encephalitis virus. Am J Trop Med Hyg 84: 718-726.

Figueiredo LTM 2000. The Brazilian flaviviruses. Microbes Infect 2: $1643-1649$

Figueiredo MLG, Gomes AC, Amarilla AA, Leandro AS, Orrico AS, Araujo RF, Castro JSM, Durigon EL, Aquino VH, Figueiredo LTM 2010. Mosquitoes infected with dengue viruses in Brazil. Virol J 7: 152.

Forattini OP 2002. Culicidologia médica: identificação, biologia, epidemiologia, Vol. 2, Edusp, São Paulo, 864 pp.

Formenti L 2015. Casos de Chikungunya no Brasil aumentam 65\% em um mês e meio. Available from: info.abril.com.br/noticias/ ciencia/2015/01/casos-de-chikungunya-no-brasil-aumentam65-em-um-mes-e-meio.shtml.

Forrester NL, Coffey LL, Weaver SC 2014. Arboviral bottlenecks and challenges to maintaining diversity and fitness during mosquito transmission. Viruses 6: 3991-4004.

Guedes DRD 2012. Análise da competência vetorial para o vírus dengue em populações naturais de Aedes aegypti e Aedes albopictus de Pernambuco, PhD Thesis, Centro de Pesquisas Aggeu Magalhães-Fiocruz, Recife, $101 \mathrm{pp}$.

Heinen LBS, Zuchi N, Cardoso BF, Santos FAL, Santos MAM, Nogueira ML, Dezengrini-Slhessarenko R 2015a. Dengue out- break in Mato Grosso, West-Central Brazil in 2011-2012. Rev Inst Med Trop Sao Paulo 57: 1-8.

Heinen LBS, Zuchi N, Serra OP, Cardoso BF, Gondim BHF, Santos MAM, Souto FJS, Paula DAJ, Dutra V, Dezengrini-Slhessarenko R 2015b. Saint Louis encephalitis virus in Mato Grosso, centralwestern Brazil. Rev Inst Med Trop Sao Paulo 57: 215-220.

Hoch AL, Pinheiro FP, Roberts DR, Gomes MLC 1987. Laboratory transmission of Oropouche virus by Culex quinquefasciatus Say. Bull Pan Am Health Organ 21: 55-61.

IBGE - Instituto Brasileiro de Geografia e Estatística 2011. Estado de Mato Grosso. Available from: ibge.gov.br/home.

Iversson LB, da Rosa APAT, Rodrigues SG, Rosa MDB 1990. Human disease caused by Venezuelan equine encephalitis subtype IF in Ribeira Valley, São Paulo, Brazil. In Proceedings of the Annual Meeting of the American Society of Tropical Medicine and Hygiene, 1990, New Orleans, ASTMH, New Orleans, p. 143.

Long KC, Ziegler SA, Thangamani S, Hausser NL, Kochel TJ, Higgs S, Tesh RB 2011. Experimental transmission of Mayaro virus by Aedes aegypti. Am J Trop Med Hyg 85: 750-757.

Luo Q 1993. A study on transmission of dengue virus by Culex fatigans. Zhonghua Liu Xing Bing Xue Za Zhi 14: 67-69.

Melo RM, Cavalcanti RC, Villalobos EMC, Cunha EMS, Lara MCCSH, Aguiar DM 2012. Ocorrência de equídeos soropositivos para os vírus das encefalomielites e anemia infecciosa no estado de Mato Grosso. Arq Inst Biol (São Paulo) 79: 169-175.

Mondini A, Cardeal ILS, Lazaro E, Nunes SH, Moreira CC, Rahal P, Maia IL, Franco C, Góngora DVN, Góngora-Rúbio F, Cabrera EMS, Figueiredo LTM, Fonseca FG, Bronzoni RVM, Chiaravalloti-Neto F, Nogueira ML 2007. Saint Louis encephalitis virus, Brazil. Emerg Infect Dis 13: 176-178.

Mourão MPG, Bastos MS, Figueiredo RP, Gimaque JBL, Galusso ES, Kramer VM, Oliveira CMC, Naveca FG, Figueiredo LTM 2012. Mayaro fever in the city of Manaus, Brazil, 2007-2008. Vector Borne Zoonotic Dis 12: 42-46.

Navarro-Silva MA, Barbosa AA, Calado D 2004. Atividade de Mansonia spp em fragmento florestal na área urbana de Curitiba, Paraná, Brasil. Rev Bras Zool 21: 243-247.

Ng TF, Willner DL, Lim YW, Schmieder R, Chau B, Nilsson C, Al E 2011. Broad surveys of DNA viral diversity obtained through viral metagenomics of mosquitoes. PLoS ONE 6: e20579.

Nogueira RMR, Eppinghaus ALF 2011. Dengue virus type 4 arrives in the state of Rio de Janeiro: a challenge for epidemiological surveillance and control. Mem Inst Oswaldo Cruz 106: 255-256.

Pauvolid-Corrêa A 2008. Estudos sobre arbovírus em populações de equinos e artrópodes na sub-região da Nhecolândia no Pantanal de Mato Grosso do Sul, MSc Thesis, Instituto Oswaldo Cruz, Rio de Janeiro, $180 \mathrm{pp}$.

Pauvolid-Corrêa A, Campos C, Juliano R, Velez J, Nogueira RMR, Komar N 2014. Serological evidence of widespread circulation of West Nile virus and other flaviviruses in equines of the Pantanal, Brazil. PLoS Negl Trop Dis 8: e2706.

Pinheiro FP, Leduc JW 1998. Mayaro fever. In TP Monath (ed.), The arboviruses: epidemiology and ecology, Vol. III, CRC Press, Boca Ratón, p. 137-150.

Powers AM, Aguilar LJC, Brault AC, Meakins AMTA, Watts D, Russel KL, Olson J, Vasconcelos PFC, da Rosa AT, Weaver SC, Tesh RB 2006. Genetic relationships among Mayaro and Una viruses suggest distinct patterns of transmission. Am J Trop Med Hyg 75: 461-469.

Powers AM, Brault AC, Shirako Y, Strauss EG, Kang W, Strauss JH, Weaver SC 2001. Evolutionary relationships and systematics of the alphaviruses. J Virol 75: 10118-10131. 
Regis L, Souza WV, Furtado AF, Fonseca CD, Silveira Jr JC, Ribeiro Jr PJ, Melo-Santos MAV, Carvalho MS, Monteiro AMV 2009. An entomological surveillance system based on open spatial information for participative dengue control. An Acad Bras Cienc 81: 655-662.

Rocco IM, Santos CLS, Bisordi I, Petrella SNCM, Pereira LE, Souza RP, Coimbra TLM, Bessa TAF, Oshiro FM, Lima LBQ, Cerroni MP, Marti AT, Barbosa VM, Katz G, Suzuki A 2005. St. Louis encephalitis virus: first isolation from a human in São Paulo state, Brasil. Rev Inst Med Trop Sao Paulo 47: 281-285.

Rodrigues SG, Oliva OP, Araujo FAA, Martins LC, Chiang JO, Henriques DF, Silva EVP, Rodrigues DSG, Prazeres ASC, TavaresNeto J, Vasconcelos PFC 2010. Epidemiology of Saint Louis encephalitis virus in the Brazilian Amazon Region and in the state of Mato Grosso do Sul, Brazil: elevated prevalence of antibodies in horses. Rev Pan-Amaz Saude 1: 81-86.

Schatzmayr HG 2001. Viroses emergentes e reemergentes. Cad Saude Publica 17: 209-213.

Segura MNO, Castro FC 2007. Atlas de culicídeos na Amazônia brasileira: caracterìsticas especificas de insetos hematófagos da familia Culicidae, Instituto Evandro Chagas, Belém, 67 pp.

SES-MT - Secretaria Estadual de Saúde do Mato Grosso 2014. Saúde do estado divulga dados da dengue de 2014 e fechamento do ano de 2013. Available from: acorimais.com.br/portal/noticias/233saude-do-estado-divulga-dados-da-dengue-de-2014-e-fechamento-do-ano-2013.

Shope RE, Causey OR, Andrade AHP, Theiler M 1964. The Venezuelan equine encephalomyelitis complex of group A arthropod-borne viruses, including Mucambo and Pixuna from the Amazon Region of Brazil. Am J Trop Med Hyg 13: 723-727.

Silva JR, Romeiro MF, Souza WM, Munhoz TD, Borges GP, Soares OAB, Campos CHC, Machado RZ, Silva MLCR, Faria JLM, Chávez JH, Figueiredo LTM 2014. A Saint Louis encephalitis and Rocio virus serosurvey in Brazilian horses. Rev Soc Bras Med Trop 47: 414-417.
Smith JL, Fonseca DM 2004. Rapid assays for identification of members of the Culex (Culex) pipiens complex, their hybrids and other sibling species (Diptera Culicidae). Am J Trop Med Hyg 70: 339-345.

Svoboda WK, Martins LC, Malanski LS, Shiozawa MM, Spohr KAH, Hilst CLS, Aguiar LM, Ludwig G, Passos FC, Silva LR, Headley SA, Navarro IT 2014. Serological evidence for Saint Louis encephalitis virus in free-ranging New World monkeys and horses within the upper Paraná River Basin region, southern Brazil. Rev Soc Bras Med Trop 47: 280-286.

Urdaneta L, Herrera F, Pernalete M, Zoghbi N, Rubio-Palis Y, Barrios R, Rivero J, Comach G, Jiménez M, Salcedo M 2005. Detection of dengue viruses in field-caught Aedes aegypti (Diptera: $\mathrm{Cu}$ licidae) in Maracay, Aragua state, Venezuela, by type-specific polymerase chain reaction. Infect Genet Evol 5: 177-184.

Vazeille M, Mousson L, Martin E, Failloux AB 2010. Orally co-infected Aedes albopictus from La Reunion Island, Indian Ocean, can deliver both dengue and Chikungunya infectious viral particles in their saliva. PLoS Negl Trop Dis 4: e706.

Vega-Rúa A, Zouache K, Girod R, Failloux AB, Lourenço-de-Oliveira R 2014. High vector competence of Aedes aegypti and Aedes albopictus from ten American countries as a crucial factor of the spread of Chikungunya. $J$ Virol doi:10.1128/JVI.00370-142014.

Vieira CJSP, Silva DJF, Barreto ES, Siqueira CEH, Colombo TE, Ozanic K, Schmidt DJ, Drumond BP, Mondini A, Nogueira ML, Bronzoni RVM 2015. Detection of Mayaro virus infection during a dengue outbreak in Mato Grosso, Brazil. Acta Trop 147: 12-16.

WHO - World Health Organization 2014. West Nile virus - Brazil. Available from: who.int/csr/don/15-december-2014-wnv/en/.

Zeidler JD, Acosta POA, Barrêto PP, Cordeiro JS 2008. Virus dengue em larvas de Aedes aegypti e sua dinâmica de infestação, Roraima, Brasil. Rev Saude Publica 42: 986-991.

Zuchi N, Heinen LBS, dos Santos MAM, Pereira FC, Slhessarenko RD 2014. Molecular detection of Mayaro virus during a dengue outbreak in the state of Mato Grosso, central-west Brazil. Mem Inst Oswaldo Cruz 109: 820-823. 